AKRUAL 3 (2) (2012): 167-195 e-ISSN: 2502-6380

AKRUAL

Jurnal Akuntansi

http://fe.unesa.ac.id/ojs/index.php/akrl

\title{
KINERJA PELAYANAN PUBLIK PEMKOT SURABAYA MENURUT PERSEPSI MASYARAKAT (SURVEY PADA DISPENDUK DAN PUSKEMAS)
}

\author{
Erina Sudaryati \\ Fakultas Ekonomi dan Bisnis Universitas Airlangga \\ E-mail: erina_unair@yahoo.com
}

Artikel diterima: 10 Januari 2012

Terakhir direvisi: 20 Februari 2012

\begin{abstract}
This study aims to analyze the performance of Local Government Task Force related to services provided Surabaya publicl community as intended by Permendagri 73/2009. And to know the correspondence between the performance of services with the expectation or level of use of public interest services Surabaya Local Government Unit according to the index specified by KepMenpan No. 25/KEP/M.PAN/2/2004, Measurement of the dimensions of service quality is the 14 indicators specified in the questionnaire KepmenPan which were translated into 33 subindikator. The population in this study were all community care service users SKPD selected, the Office of Population and Civil serving the needs of birth certificates and service records related to identity issues and health centers (one selected health centers in the suburbs, namely Eastern Surabaya). While samples taken accidental sampling, ie respondents who can be found by the researchers. Results showed that administration of the health center service is good but still can be improved and Dispenduk still not satisfactory.
\end{abstract}

Keywords: SKPD service performance, the satisfaction index

\section{PENDAHULUAN}

\section{Latar Belakang}

Upaya pemerintah dalam mensejahterakan rakyatnya melalui pelayanan masih menjadi pekerjaan rumah yang sangat dan harus lebih diperhatikan. Upaya tersebut sampai sekarang masih menjadi titik fokus pembenahan, yang diperhatikan pula oleh masyarakat. Era globalisasi yang penuh tantangan dan peluang, dalam hal ini dititikberatkan kepada aparatur pemerintahan hendaknya memberikan pelayanan yang sebaik-baiknya, berorientasi kepada kebutuhan-kebutuhan dan kepuasan penerima pelayanan, sehingga dapat meningkatkan daya saing dalam pemberian pelayanan berupa barang maupun jasa.

Hakekatnya pelayanan publik merupakan pemberian pelayanan prima kepada masyarakat yang merupakan kewajiban aparatur pemerintah sebagai abdi masyarakat. Pengembangan kinerja pelayanan publik senantiasa menyangkut tiga unsur pokok pelayanan publik yakni unsur kelembagaan penyelenggaraan pelayanan, proses 
pelayanan dan sumber daya pemberi pelayanan. Oleh karena itu upaya peningkatan kinerja pelayanan publik senantiasa berkenaan dengan pengembangan tiga unsur pokok tersebut (Surjadi,2009:9).

Idealnya pelayanan publik yang merupakan hak rakyat tersebut, sudah menjadi kewajiban pemerintah untuk memenuhinya. Namun dalam kenyataannya saat ini hak-hak tersebut tidak dapat diperoleh masyarakat sebagaimana mestinya yang tercantum dalam sila ke-lima yang berbunyi keadilan sosial bagi seluruh rakyat Indonesia. Salah satu bentuk pelayanan yang sering diperhatikan oleh masyarakat adalah pelayanan bidang kesehatan dan kependudukan.

Tuntutan ke arah pelayanan prima mensyaratkan adanya Standar Minimal Pelayanan (Dwiyanto dkk, 2003) menjadi tolak ukur bagi mutu pelayanan pemerintah. Hampir semua lembaga pemerintahan telah memiliki standar ini, namun apakah telah diimplementasikan tentu jawabannya ada pada fakta dan pandangan publik atas hal tersebut.

Berdasarkan beberapa penelitian yang dilakukan kalangan akademisi dan birokrat tentang pelayanan publik di Indonesia, ternyata kondisinya masih belum baik dan memuaskan. Hal ini ditunjukkan dari kesimpulan yang dibuat oleh Dwiyanto, dkk (2003:102), dalam GDS (Governance and Decentralization) 2002 di 20 propinsi di Indonesia tentang kinerja pelayanan publik menyebutkan “... secara umum praktik penyelenggaraan pelayanan publik masih jauh dari prinsip-prinsip tata pemerintahan yang baik".

Hal ini ditunjukkan dengan masih munculnya berbagai keluhan masyarakat melalui media masa (Semil, 2005). Jika kondisi ini tidak direspon oleh pemerintah maka akan dapat menimbulkan citra yang kurang baik terhadap pemerintah sendiri. Mengingat fungsi utama pemerintah adalah melayani masyarakat maka pemerintah perlu terus berupaya meningkatkan kualitas pelayanan publik dengan mengeluarkan pedoman tentang pengukuran Indeks Kepuasan Masyarakat (MenPAN,2004: 5). Dalam konteks pelayanan publik, dikemukakan bahwa pelayanan umum adalah mendahulukan kepentingan umum, mempermudah urusan publik, mempersingkat waktu pelaksanaan urusan publik dan memberikan kepuasan kepada publik (publik/umum).

Pemerintah Daerah Kota Surabaya, yang dipimpin seorang walikota wanita dengan segudang prestasi telah banyak menunjukkan kinerjanya, namun demikian kinerja satuan kerja yang ada di lingkungan pemerintah daerah Kota Surabaya ternyata belum dapat menyamai kinerja ibu walikota secara pribadi. Hasil survey pendahuluan melalui wawancara langsung pada masyarakat yang membutuhkan pelayanan maupun dari keluhan masyarakat di surat pembaca dan radio-radio yang memprogramkan untuk menampung keluhan masyarakat atas pelayanan aparat pemerintah menunjukkan kualitas pelayanan unit pemerintahan di Pemerintah Kota Surabaya masih jauh dari memuaskan.

Berangkat dari persoalan mempertanyakan kepuasan masyarakat terhadap apa yang diberikan oleh pelayan dalam hal ini yaitu aparat pemerintahan, maka perlu dilakukan penelitian tentang kinerja pemerintah daerah, dalam hal ini Satuan Kerja 
Pemerintah Daerah yang langsung memberikan pelayanan kepada masyarakat dengan melalui pengukuran kepuasan masyarakat melalui indeks yang sudah ditentukan oleh Kepmenpan.

\section{Perumusan Masalah}

Berdasarkan uraian pada latar belakang, maka masalah yang ingin diteliti dalam penelitian ini adalah dalam penelitian ini adalah:

1. Bagaimana kinerja pelayanan publik yang diberikan Satuan Kerja Pemerintah Daerah Kota Surabaya kepada masyarakat?

2. Apakah pelayanan yang diberikan terdapat kesesuaian dengan harapan masyarakat minimal sesuai dengan standar pelayananan minimal?

Penelitian ini merupakan suatu penelitian survei yang melakukan identifikasi dan pengukuran kinerja pelayanan publik melalui pengukuran Indeks Kepuasan Masyarakat Kota Surabaya atas pelayanan yang diberikan oleh satuan kerja di lingkungan Pemerintah Daerah Surabaya. Indeks Kepuasan Masyarakat merupakan suatu indikator kinerja pemerintah sesuai dengan yang tercantum dalam dalam Peraturan Pemerintah Nomor 6 tahun 2008 dan Peraturan Pemerintah No. 3 tahun 2007. Tidak semua satuan kerja yang ada di pemerintahan melakukan pelayanan kepada masyarakat, oleh karena itu penelitian ini dibatasi pada satuan kerja pemerintah yang berkaitan langsung dengan pelayanan kepada masyarakat. Dasar pengukuran kepuasan masyarakat melalui indeks ini adalah sesuai dengan yang ditetapkan oleh KepMenpan No. 25/KEP/M.PAN/2/2004.

\section{Tujuan Penelitian}

Penelitian ini bertujuan untuk menganalisis kinerja Satuan Kerja Pemerintah Daerah Surabaya terkait pelayanan yang diberikan publik/ masyarakat sebagaimana dimaksudkan oleh Permendagri 73/2009 serta mengetahui kesesuaian antara kinerja layanan dengan harapan atau tingkat kepentingan masyarakat penggunan jasa pelayanan Satuan Kerja Pemerintah Daerah Surabaya sesuai indeks yang ditentukan oleh KepMenpan No. 25/KEP/M.PAN/2/2004

\section{KAJIAN PUSTAKA Otonomi Daerah}

Otonomi daerah yang berlangsung sejak reformasi telah mengubah konsep kebijakan pelayanan publik lebih berorientasi pelayanan yang bertujuan untuk meningkatkan pelayanan kepada masyarakat (pelanggan) dan memberdayakan (empowerment) staf penyelenggara pelayanan dan masyarakat. Oleh karena itu, bobot orientasi pelayanan publik, seharusnya untuk kepentingan dan kebutuhan masyarakat yang kurang mampu atau miskin, Apapun alasannya, tidak seharusnya pelayanan mengutamakan hak-hak atau kepentingan kalangan yang berkemampuan atau pengusaha. Diperlukan keseimbangan pola pikir dari para penyelenggara pelayanan di dalam menyikapi kondisi nyata di daerah. Satuan Kerja Perangkat Daerah 
selanjutnya disingkat SKPD adalah perangkat daerah yang bertanggungjawab atas pelaksanaan urusan pemerintahan daerah.

Dalam penyelenggaran pemerintahan, maka pemerintah daerah diharuskan menyusun Laporan Penyelenggaran Pemerintah Daerah selanjutnya disingkat LPPD adalah laporan atas penyelenggaraan pemerintahan daerah dalam kurun waktu I (satu) tahun anggaran berdasarkan Rencana Kerja Pembangunan Daerah yang disampaikan oleh Kepala Daerah kepada Pemerintah. Hal ini agar kinerja pemerintah daerah dapat terus dipantau. Kinerja Penyelengaraan Pemerintahan Daerah adalah capaian atas penyelenggararaan urusan pemerintahan daerah yang diukur dari masukan, proses, keluaran, hasil, manfaat, dan/atau dampak.

Untuk mengetahui capaian suatu pemerintah daerah perlu dilakukan Evaluasi Penyelenggaraan Pemerintahan Daerah selanjutnya disingkat EPPD yang merupakan suatu proses pengumpulan dan analisis data secara sistematis terhadap kinerja penyelenggaraan pemerintahan daerah, kemampuan penyelenggaraan otonomi daerah, dan kelengkapan aspek-aspek penyelengaraan pemeritahan pada daerah yang baru dibentuk. Selain itu juga dilakukan suatu Evaluasi Kinerja Penyelenggaraan Pemerintahan Daerah selanjutnya disingkat EKPPD yang merupakan suatu proses pengumpulan dan analisis data secara sistematis terhadap kinerja penyelenggaraan pemerintahan daerah dengan menggunakan sistem pengukuran kinerja.

Sistem pengukuran kinerja adalah sistem yang digunakan untuk mengukur, menilai dan membandingkan secara sistematis dan berkesinambungan atas kinerja penyelenggaraan pemerintahan daerah. Indikator Kinerja adalah alat ukur spesifik secara kuantitatif yang terdiri dari unsur masukan, proses, keluaran, hasil, manfaat, dan/atau dampak yang menggambarkan tingkat capaian kinerja suatu kegiatan. Indikator kinerja untuk pemerintahan pusat dan kementerian/kelembagaan berbeda dengan indikator kinerja untuk pemerintah daerah dalam hal ini pemerintah propinsi dan pemerintah kabupaten/kota.

Berdasarakan SE Mendagri tentang Penyempurnaan Indikator Kinerja Kunci tertanggal 09 Oktober 2008, aspek yang menjadi fokus penilaiakan kinerja untuk pemerintah propinsi terdiri dari 13 aspek, 41 fokus dan 45 indikator kinerja kunci, sedangkan untuk pemerintah kota m,eliputi 13 aspek, 43 fokus dan 51 indikator kinerja kunci dan untuk pemerintah kabupaten meliputi 13 aspek dengan 43 fokus dan 51 indikator kinerja kunci.

\section{Kinerja Pemerintah Daerah dan Kinerja SKPD}

Menurut Permendagri No. 73 tahun 2009 dalam ayat 16, sistem pengukuran kinerja sebagaimana dimaksud pada ayat (1) mencakup:

a. Penetapan IKK;

b. Teknik pengumpulan data kinerja;

c. Metodologi pengukuran kinerja; dan

d. Analisis, pembobotan, dan interpretasi kinerja. 
Evaluasi kinerja pemerintah daerah sesuai dengan pasal 60 PP No. 6 tahun 2008, EKPPD yang dilaksanakan sejak 2008 menggunakan aspek, fokus dan indikator tataran pelaksanaan kebijakan untuk tingkatan SKPD sesuai dengan SE Mendagri Tentang Penyempurnaan Indikator Kinerja Kunci tertanggal 09 Oktober 2008 terdiri dari:

1. Kebijakan teknis penyelenggaraan urusan pemerintahan

2. Ketaatan peraturan / UU

3. Tingkat Capaian SPM

4. Penataan kelembagaan daerah

5. Pengelolaan kepegawaian daerah

6. Perencanaan Pembangunan daerah

7. Pengelolaan keuangan daerah

8. Pengelolaan barang milik daerah

9. Fasilitasi terhadap partisipasi masyarakat

Khusus untuk penilaian kinerja SKPD yang tertuang dalam 9 IKK tersebut. Hasil pencapaian kinerja disampaikan oleh Kepala SKPD kepada Tim Penilai untuk dilakukan pemeringkatan SKPD. Penilaian dilakukan berdasarkan tahapan sebagai berikut:

a. Mengumpulkan dan memvalidasi data capaian kinerja pada tataran pengambil kebijakan dan pelaksana kebijakan dari seluruh SKPD;

b. Mengintegrasikan dan mensinkronisasikan data capaian kinerja dari seluruh SKPD;

c. Mengkaji dan menganalisis, konfirmasi, verifikasi, validasi data capaian kinerja pada tataran pengambil kebijakan dan pelaksana kebijakan;

d. Mendiskusikan dan menginterprestasikan hasil penilaian capaian kinerja penyelenggaraan pemerintahan daerah dengan sistem pengukuran dan indikatornya untuk membandingkan keberhasilan tahun sebelumnya; dan

e. Memperingkat kinerja masing-masing SKPD dengan penilaian menggunakan sistem pengukuran IKK pada tataran pelaksana kebijakan yang meliputi:

1. Administrasi umum;

2. Capaian kinerja urusan wajib dan urusan pilihan;

3. Penilaian atas realisasi pelaksanaan program tahun yang dievaluasi dan dibandingkan dengan tahun-tahun sebelumnya; dan

4. Penilaian seluruh realisasi kinerja SKPD.

Terkait dengan Sembilan indikator pencapaian kinerja SKPD tersebut, maka indikator ke tiga yaitu tingkat capaian SPM merupakan suatu indikator yang menunjukkan bagaimana suatu SKPD memberikan pelayananan minimal kepada masyarakat.

Pemberian Pelayananan kepada masyarakat diatur dengan pembuatan standar pelayanan minimal atau SPM. Standar pelayanan minimal harus mampu memenuhi harapan masyarakat. Apabila suatu SKPD mampu memberikan pelayananan minimal yang sesuai dengan pelayanan yang diharapkan masyarakat, maka tidak akan terdapat kesenjangan atara harapan dengan pelayanan sehingga masyarakat akan merasa puas. 
Ukuran kepuasan masyarakat yang menjadi salah satu tolak ukur kinerja suatu SKPD pengukurannya berdasarkan pedoman yang sudah ditetapkan pemerintah yaitu oleh KepMenpan No. 25/KEP/M.PAN/2/2004 telah menyusun 14 indikator standar penilaian Kepuasan Masyarakat yang harus dilakukan oleh instansi pemerintah untuk menilai kinerja pelayanan publik di Pemerintah meliputi: prosedur pelayanan; persyaratan pelayanan; kejelasan petugas pelayanan; kedisiplinan petugas pelayanan; tanggung jawab petugas pelayanan; kemampuan petugas pelayanan; kecepatan pelayanan; keadilan mendapatkan pelayanan; kesopanan dan keramahan petugas; kewajaran biaya pelayanan; kepastian biaya pelayanan; kepastian jadwal pelayanan; kenyamanan lingkungan; serta keamanan pelayanan.

Pelayanan publik sebagai salah satu bentuk barang publik (public goods) yang diberikan pemerintah sudah selayaknya diimbangi dengan kualitas layanan yang baik, sehingga masyarakat akan menaruh kepercayaan kepada pemerintah (Bastian, 2010). Pelayanan publik yang prima akan menghasilkan kepuasan masyarakat terhadap kinerja pemerintah, yang selanjutnya akan mendorong masyarakat untuk mendukung dan mentaati pemerintah karena kesadaran dan kesukarelaan, bukan karena paksaan. Ke-14 indikator yang akan dijadikan instrumen pengukuran adalah sebagai berikut:

1. Prosedur pelayanan, yaitu kemudahan tahapan pelayanan yang diberikan kepada masyarakat dilihat dari sisi kesederhanaan alur pelayanan dengan kriteria-kriteria antara lain (1) kesederhanaan yaitu bahwa prosedur atau tata cara pelayanan diselenggarakan secara mudah, lancar, cepat, tidak berbelit-belit, mudah dipahami dan dilaksanakan oleh yang meminta pelayanan, (2) Adanya kejelasan dan kepastian mengenai prosedur atau tatacara pelayanan, (3) Adanya keterbukaan dalam prosedur pelayanan.

2. Persyaratan pelayanan, yaitu persyaratan teknis dan administratif yang diperlukan untuk mendapatkan pelayanan sesuai dengan jenis pelayanannya. Dengan kriteria-kriteria antara lain (1) Adanya kejelasan persyaratan pelayanan baik teknis maupun administrasi, (2) Keterbukaan mengenai persyaratan pelayanan, (3) Efisiensi persyaratan dalam arti bahwa dibatasi pada hal-hal yang berkaitan langsung dengan pelayanan serta dicegah adanya pengulangan pemenuhan persyaratan.

3. Kejelasan petugas pelayanan, yaitu keberadaan dan kepastian petugas yang memberikan pelayanan (nama, jabatan, serta kewenangan dan tanggung jawab dengan kriteria-kriteria antara lain (1) Responsiveness yaitu kesediaan untuk membantu pelanggan dengan menyediakan pelayanan yang cocok seperti yang mereka inginkan, (2) Access yaitu mudah melakukan kontak dengan penyedia jasa.

4. Kedisiplinan petugas pelayanan, yaitu kesungguhan petugas dalam memberikan pelayanan terutama terhadap konsistensi waktu kerja sesuai ketentuan yang berlaku.

5. Tanggung jawab petugas pelayanan yaitu kejelasan wewenang dan tanggung jawab dalam penyelenggaraan dan penyelesaian pelayanan dengankriteriakriteria antara lain (1) Kejelasan dan kepastian unit kerja atau pejabat yang 
berwenang dan bertanggung jawab dalam memberikan pelayanan, (2) Keterbukaan mengenai satuan kerja/ pejabat penanggungjawab pemberi pelayanan.

6. Kemampuan petugas pelayanan, yaitu tingkat keahlian dan keterampilan yang dimiliki petugas dalam memberikan/menyelesaikan pelayanan kepada masyarakat. mengemukakan beberapa unsur untuk menilai kualitas jasa yang antara lain (1) Profesionalism and Skill; yang berkaitan dengan pengetahuan dan keterampilan (intelektual, fisik, administrasi maupun konseptual) yang dibutuhkan untuk memecahkan masalah pelanggan secara profesional.

7. Kecepatan pelayanan, yaitu target waktu pelayanan dapat diselesaikan dalam waktu yang telah ditentukan oleh unit penyelenggara pelayanan digunakan kriteriakriteria antara lain (1) Keterbukaan waktu penyelesaian, (2) Ketepatan waktu yaitu bahwa pelaksanaan pelayanan publik dapat diseleaikan dalam kurun waktu yang telah ditentukan.

8. Keadilan mendapatkan pelayanan, yaitu pelaksanaan pelayanan dengan tidak membedakan golongan/status masyarakat yang dilayani digunakan kriteriakriteria antara lain (1) Keadilan yang merata yaitu bahwa cakupan/jangkauan pelayanan harus diusahakan seluas mungkin dengan distribusi yang merata dan diberlakukan.

9. Kesopanan dan keramahan petugas, yaitu sikap dan perilaku petugas dalam memberikan pelayanan kepada masyarakat secara sopan dan ramah serta saling menghargai dan menghormati dengan kriteria antara lain (1) Assurance yaitu kemampuan dan keramahan serta sopan sanun pegawai dalam meyakinkan kepercayaan konsumen, (2) Emphaty yaitu sikap tegas tetapi penuh perhatian dari pegawai terhadap konsumen.

10. Kewajaran biaya pelayanan, yaitu keterjangkauan masyarakat terhadap besarnya biaya yang ditetapkan oleh unit pelayan dengan kriteria antara lain (1) Reputation and Credibility yaitu pelanggan menyakini bahwa operasi dari penyedia jasa dapat dipercaya dan memberikan nilai atau imbalan yang sesuai dengan pengorbanannya atau biayanya.

11. Kepastian biaya pelayanan, yaitu kesesuaian antara biaya yang dibayarkan dengan biaya yang telah ditetapkan dengan kriteriakriteria antara lain (1) Kejelasan dan kepastian mengenai rincian biaya/tariff pelayanan dan tatacara pembayarannya, (2) Keterbukaan mengenai rincian biaya/tariff pelayanan.

12. Kepastian jadwal pelayanan, yaitu pelaksanaan waktu pelayanan, sesuai dengan ketentuan yang telah ditetapkan dengan digunakan kriteria-kriteria antara lain (1) Reability (keandalan) yaitu menilai tingkat dimana pelayanan pemerintah disediakan secara benar dan tepat waktu.

13. Kenyamanan lingkungan, yaitu kondisi sarana dan prasarana pelayanan yang bersih, rapi dan teratur sehingga dapat memberikan rasa nyaman kepada penerima pelayanan digunakan kriteria-kriteria antara lain (1) Kenyamanan dalam memperoleh pelayanan yang berkaitan dengan lokasi, ruang tempat pelayanan, kemudahan menjangkau, ketersediaan informasi dan lain-lain, (2) 
Atribut pendukung pelayanan lainnya yang berkaitan dengan lingkungan, kebersihan, ruang tunggu, fasilitas musik dan lain-lain.

14. Keamanan pelayanan, yaitu terjaminnnya tingkat keamanan lingkungan unit penyelenggara pelayanan ataupun sarana yang digunakan, sehingga masyarakat merasa tenang untuk mendapatkan pelayanan terhadap resikoresiko yang diakibatkan dari pelaksanaan pelayanan dengan kriteria (1) keamanan pelayanan dan ,(2) kenyamanan pelayanan.

\section{METODE PENELITIAN}

\section{Pendekatan Penelitian}

Sesuai dengan tujuan penelitian yang telah dikemukakan, maka penelitian ini menggunakan rancangan atau desain penelitian deskriptif kualitatif untuk mengetahui indeks kepuasan masyarakat dari pelayanan

\section{Lokasi dan Obyek Penelitian}

Lokasi penelitian ini tepatnya di satuan kerja-satuan kerja pemerintah daerah selanjutnya disebut SKPD) di Surabaya.SKPD yang dipilih..Penelitian ini ingin menganalisis kinerja pelayanan publik di SKPD Pemda Surabaya dengan cara mengukur indeks kepuasan masyarakat yang dilayani. Salah satu tolok ukur penilaian kinerja pelayanan adalah dengan mendengarkan atau mengumpulkan persepsi dari responden atas pelayanan yang telah diterimanya. Dengan mendengarkan atau mengumpulkan persepsi dari responden mengenai kualitas pelayanan yang telah diterimanya dengan pengukuran mengacu pada Kepmen PAN Nomor : KEP/25/M.PAN/2004.

\section{Identifikasi dan Difinisi Variabel}

Variabel yang diteliti adalah variabel Kualitas Pelayanan SKPD yang diukur dengan 14 indikator dan 33 sub indikator serta variabel Indeks Kepuasan Masyarakat. Variabel Kualitas Pelayanan SKPD dalam penelitian ini adalah pelayanan yang diberikan telah sesuai dengan yang diharapkan masyarakat sehingga kualitas pelayanan telah dipersepsikan cukup baik. Pengukuran dimensi kualitas layanan ini dengan 14 indikator yang ditetapkan KepmenPan yang dalam kuesioner dijabarkan dalam 33 subindikator. Adapun Dimensi Kualitas Pelayanan beserta indicator dan sub indicator dapat dilihat pada lampiran.

\section{Jenis dan Sumber Data}

Data yang digunakan dalam penelitian ini berupa data primer dan data sekunder. Data Primer merupakan data yang diperoleh melalui responden yang dijadikan sampel yaitu masyarakat yang membutuhkan jasa SKPD berupa pernyataan atau memberikan jawaban melalui kuesioner untuk mengetahui kepuasan masyarakat dan kualitas pelayanan maupun melalui in kuesioner yang dibagikan dan depth interview untuk menggali informasi lebih dalam tentang tuntutan masyarakat akan kualitas pelayanan. Sedangkan data sekunder yaitu data yang diperoleh dari 
catatan-catatan, buku, makalah, monografi dan lain-lain terutama yang berkaitan dengan permasalahan penelitian. Data yang lain juga didapat dari arsip, sebagai sumber data dalam bentuk dokumen, data statistik dan naskah-naskah yang telah tersedia dalam lembaga atau instansi yang berhubungan dengan penelitian ini.

\section{Instrumen Penelitian}

Instrumen penelitian yang akan digunakan adalah kuesioner. Oleh karena Kepmen mensyaratkan untuk menilai kinerja kualitas pelayanan SKPD harus dilakukan pada persepsi minimal dari 150 orang responden untuk masing-masing SKPD dalam bentuk rating scale sesuai dengan skala pengukuran yang dipakai.

\section{Populasi dan Teknik Pengambilan Sampel}

Populasi dalam penelitian ini adalah seluruh masyarakat pengguna jasa pelayanan SKPD yang dipilih. Oleh karena KepmenPan mensyaratkan minimal 150 orang untuk setiap SKPD maka penelitian ini membatasi populasi hanya pada masyarakat pengguna jasa di SKPD yang banyak mendapat keluhan atau komplain atas pelayanan yang diberikan. Adapun SKPD yang dipilih dalam penelitian ini adalah secara langsung melayani masyarakat luas, yaitu Kantor Kependudukan dan Catatan Sipil yang melayani kebutuhan pencatatan akta kelahiran dan pelayanan terkait dengan masalah identitas dan Puskesmas (dipilih Puskesmas satu di pinggir kota, yaitu Surabaya Timur). Sedangkan sampel diambil secara accidental sampling, yaitu responden yang dapat ditemui oleh peneliti. Sampel yang dijadikan responden dalam penelitian ini sebanyak 150 responden untuk setiap SKPD .

\section{Teknik Analisis Data}

Dalam penelitian ini teknik analisis deskriptip naratif, dengan perhitungan datanya dilakukan dengan menggunakan nilai Indeks Kepuasan Masyarakat (IKM) yang dihitung denganmenggunakan nilai rata-rata tertimbang masing-masing unsur pelayanan. Dalam penghitungan IKM terdapat 14 unsur atau indikator yang dikaji. Setiap unsur dihitung dengan bobot nilai rata-rata tertimbang sebagai berikut:

$$
\begin{aligned}
& \text { Bobot Nilai Rata } \\
& \text { Rata Tertimbang }
\end{aligned}=\frac{\text { Jumlah Bobot }}{\text { Jumlah Unsur }}=\frac{1}{14}=0,071
$$

Untuk memperoleh Nilai IKM diperoleh dengan rumus sebagai berikut:

$$
\text { IKM }=\frac{\text { Total Nilai Persepsi per Unsur }}{\text { Total unsur terisi }} \times \text { nilai penimbang }
$$

Guna mempermudah interpretasi nilai IKM yang berkisar 25 - 100, maka hasil penilaian masing-masing dikalikan 150 .

Nilai IKM Unit Pelayanan X 25 
Tabel 1. Nilai Persepsi, Interval IKM, Interval Konversi IKM

\begin{tabular}{ccccc}
\hline No. & Nilai Interval & Konversi IKM & Mutu Pelayanan & Kinerja Unit Layanan \\
\hline 1 & $1,00-1,75$ & $25-43,75$ & $\mathrm{D}$ & Sangat Tidak Bagus \\
2 & $1,75-2,50$ & $43,76-62,75$ & $\mathrm{C}$ & Tidak Bagus \\
3 & $2,50-3,25$ & $62.76-81,25$ & $\mathrm{~B}$ & Bagus \\
4 & $3,25-4,00$ & $81,26-100$ & $\mathrm{~A}$ & Sangat Bagus \\
\hline
\end{tabular}

Sementara itu, untuk menentukan kinerja setiap sub indikator adalah dengan menetukan intervalnya terlebih dahulu. Rumus yang dipakai adalah:

$$
I=\frac{\text { Range }}{\Sigma K}
$$

Keterangan:

I = Interval/Rentang Kelas.

Range $=$ Skor Tertinggi - Skor Terendah

$\mathrm{K} \quad$ = Banyaknya Kelas yang

Kemudian untuk menjawab perumusan masalah dalam penelitian ini, digunakan Importance -Performance Analysis untuk melihat tingkat kesesuaian antara harapan dan kualitas pelayanan:

a. Tingkat Kesesuaian

$$
T K i=\frac{Y i}{X i}-X^{-100 \%}
$$

Keterangan:

$$
\begin{aligned}
& \mathrm{Tki}=\text { Tingkat kesesuaian responden } \\
& \mathrm{Xi}=\text { Skor penilaian kualitas pelayanan } \\
& \mathrm{Yi}=\text { Skor penilaian kepentingan }
\end{aligned}
$$

b. Skor Rata - Rata

$$
X=\sum_{n} X i \quad Y=\sum_{n}^{\sum Y i}
$$

Keterangan:

$$
\begin{aligned}
& \mathrm{X}=\text { Skor rata-rata tingkat kepuasan } \\
& \mathrm{Y}=\text { Skor rata-rata tingkat kepentingan } \\
& \mathrm{n}=\text { Jumlah responden }
\end{aligned}
$$


c. Rata-rata dari rata-rata skor

$$
X=\frac{N i=1 X i}{K} \quad Y=\frac{N i=1 Y i}{K}
$$

Keterangan:

$$
\begin{aligned}
& \mathrm{X}=\text { Rata-rata dari rata-rata skor tingkat kepuasan } \\
& \mathrm{Y}=\text { Rata-rata dari rata-rata skor tingkat kepentingan } \\
& \mathrm{K}=\text { Banyaknya indikator atau sub indikator }
\end{aligned}
$$

\section{HASIL DAN PEMBAHASAN}

\section{Data Demografi Responden}

Pengumpulan data yang dilakukan selama sebulan di dua lokasi yaitu Kantor Dinas Kependudukan dan Catatan Sipil dan Puskesmas di pinggiran Surabaya Timur

\begin{tabular}{|c|c|c|c|c|c|c|c|}
\hline \multirow[t]{2}{*}{ No } & \multirow[t]{2}{*}{ Demografi Responden } & \multicolumn{2}{|c|}{ Dispenduk } & \multicolumn{2}{|c|}{ Puskesmas } & \multicolumn{2}{|c|}{ Total } \\
\hline & & Frek. & $\%$ & Frek. & $\%$ & Frek. & $\%$ \\
\hline \multirow[t]{6}{*}{1} & Tingkat Pendidikan & & & & & & \\
\hline & Sarjana $(\mathrm{S} 1, \mathrm{~S} 2, \mathrm{~S} 3)$ & 48 & 32 & 18 & 12 & 66 & 22 \\
\hline & Diploma & 44 & 29.3 & 26 & 17,3 & 60 & 20 \\
\hline & SMA & 58 & 38,7 & 72 & 48 & 118 & 39,3 \\
\hline & SMP kebawah & - & - & 34 & 22,7 & 56 & 18,7 \\
\hline & Total & 150 & 100 & 150 & 100 & 300 & 100 \\
\hline \multirow[t]{8}{*}{2.} & Umur: & & & & & & \\
\hline & $>40$ tahun & 25 & 16,7 & 57 & 28 & 82 & 27,3 \\
\hline & $35-40$ & 22 & 14,7 & 38 & 25.3 & 60 & 20 \\
\hline & $30-35$ & 31 & 20,7 & 4 & 2,7 & 35 & 11.7 \\
\hline & $25-30$ & 28 & 18,7 & 18 & 12 & 46 & 15.3 \\
\hline & $20-25$ & 44 & 29,2 & 8 & 5,3 & 52 & 17,4 \\
\hline & $<20$ & - & & 25 & 16,7 & 25 & 8,6 \\
\hline & Total & 150 & 100 & 150 & 100 & 300 & 100 \\
\hline \multirow[t]{6}{*}{3.} & Pekerjaan & & & & & & \\
\hline & Wiraswasta & 38 & 25,3 & 18 & 12 & 56 & 18,7 \\
\hline & PNS/TNI/POLRI & 26 & 17.3 & 39 & 26 & 65 & 21.7 \\
\hline & Karyawan & 42 & 28 & 25 & 16.7 & 67 & 22.3 \\
\hline & Lainnya & 44 & 29,4 & 68 & 14,3 & 112 & 37,3 \\
\hline & Total & 150 & 100 & 150 & 100 & 300 & 100 \\
\hline \multirow[t]{4}{*}{4.} & Jenis Kelamin & & & & & & \\
\hline & Wanita & 62 & 41,3 & 114 & 76 & 176 & 58,7 \\
\hline & Pria & 88 & 58,6 & 36 & 24 & 124 & 41,3 \\
\hline & Total & 150 & 100 & 150 & 100 & 300 & 100 \\
\hline
\end{tabular}
masing-masing sebanyak 150 responden. Berikut adalah data demografi responden dalam tabel berikut ini.

Tabel 2. Data Demografi Responden

Sumber: Data Yang Telah Diolah 
Berdasarkan Tabel 2 dapat diketahui bahwa secara total sebagian besar pendidikan responden setingkat SMA 118 orang atau 39,3\% disusul sarjana sebesar 66 orang atau $22 \%$, diploma orang 60 atau 20\% sisanya adalah SMP kebawah 56 orang atau 18,7 \%. Dilihat dari usia terbanyak adalah sebanyak responden $(24,67 \%)$. Sementara bila dilihat dari usia, usi responden didominasi sekitar 40 tahun ke atas sebanyak 82 orang atau $47 \%$, disusul usia 35 sampai 40 tahun sebanyak 60 orang atau $20 \%$, kemudian diikuti usia 20 sampai 25 tahun sebanyak 52 orang atau 17,4 \%, kemudian usia 25 sampai 30 tahun sebanyak 46 orang atau 15,3\% diikuti usia 30 sampai 35 tahun sebanyak 35 orang atau $11,7 \%$ dan yang paling sedikit usia dibawah 20 tahun sekitar 25 orang atau 8,6 \%. Bila dilihat dari pekerjaan responden didominasi oleh pekerjaan lainnya yang bervariasi ada ibu rumahtangga, pelajar, buruh dan sebagainya sekitar 112 orang atau 37.3\% diikuti oleh karyawan sebanyak 67 orang atau 22,3 \% kemudian PNS,TNI dan POLRI sebanyak 65 orang atau 21,7 \% dan yang terendah adalah wiraswasta sebanyal 56 oang atau 18,7 \%. Dilihat dari jenis kelamin terbanyak adalah wanita sebesar 176 orang atau 58,7\% sedangkan pria sebanyak 124 atau 41,3\%.

Dari tabel data demografis tersebut tampak bahwa kebanyakan status sosial dan pendidikan dapat dikatakan berasal dari golongan menengah dan terdidik, namun dapat dikatakan bahwa terdapat perbedaan penyebaran data demografis responden segi pendidikan yang mendatangi Dispenduk lebih terdidik di banding Puskesmas.

\section{Penilaian Kinerja Pelayanan Publik SKPD yang diteliti menurut persepsi masyarakat}

Berikut ini tabulasi dari hasil jawaban responden yang dikumpulan untuk ke dua SKDP yang menjadi obyek penelitian. Berikut ini hasil tabulasi dari jawaban responden atas pelayanan publik yang mereka terima untuk setiap item dalam 14 indikator yang mencerminkan kepuasan pelayanan publik.

Tabel 3. Rekapitulasi Jawaban Responden

\begin{tabular}{|c|c|c|c|c|c|c|c|c|c|}
\hline \multirow[t]{2}{*}{ No } & \multirow[t]{2}{*}{ Aspek Yang Dinilai } & \multicolumn{4}{|c|}{ Dispenduk } & \multicolumn{4}{|c|}{ Puskesmas } \\
\hline & & 1 & 2 & 3 & 4 & 1 & 2 & 3 & 4 \\
\hline 1 & PROSEDUR PELAYANAN & & & & & & & & \\
\hline 1. & Keterbukaan Informasi & 11 & 28 & 79 & 32 & 10 & 34 & 71 & 35 \\
\hline 2. & Prosedur Pelayanan & 9 & 31 & 68 & 42 & 9 & 30 & 81 & 30 \\
\hline 3. & $\begin{array}{l}\text { Kejelasan alur dalam prosedur } \\
\text { pelayanan. } \\
\text { Kesederhanaan mengenai } \\
\text { prosedur pelayanan }\end{array}$ & 13 & 37 & 71 & 29 & 11 & 32 & 79 & 28 \\
\hline 2 & PERSYARATAN PELAYAN & & & & & & & & \\
\hline 4. & Keterbukaan mengenai & 8 & 25 & 81 & 36 & 9 & 27 & 78 & 36 \\
\hline 5. & persyaratan pelayanan & 14 & 31 & 75 & 30 & 13 & 36 & 83 & 18 \\
\hline 6. & $\begin{array}{l}\text { Kemudahan mengurus / } \\
\text { memenuhi persyaratan }\end{array}$ & 9 & 26 & 92 & 23 & 9 & 29 & 81 & 31 \\
\hline
\end{tabular}




\begin{tabular}{|c|c|c|c|c|c|c|c|c|c|}
\hline \multirow[t]{2}{*}{ No } & \multirow[t]{2}{*}{ Aspek Yang Dinilai } & \multicolumn{4}{|c|}{ Dispenduk } & \multicolumn{4}{|c|}{ Puskesmas } \\
\hline & & 1 & 2 & 3 & 4 & 1 & 2 & 3 & 4 \\
\hline & $\begin{array}{l}\text { pelayanan. } \\
\text { Kejelasan mengenai persyaratan } \\
\text { pelayanan. }\end{array}$ & & & & & & & & \\
\hline 3 & KEJELASAN PELAYANAN & & & & & & & & \\
\hline 7. & Kepastian mengenai identitas & 8 & 13 & 83 & 46 & 8 & 17 & 76 & 49 \\
\hline 8. & $\begin{array}{l}\text { dan tanggung jawab petugas } \\
\text { pelayanan } \\
\text { Kemudahan menemui/ } \\
\text { menghubungi petugas } \\
\text { pelayanan. }\end{array}$ & 6 & 27 & 87 & 30 & 7 & 31 & 78 & 34 \\
\hline 4 & KEDISIPLINAN PETUGAN PI & LAYA & $\mathbf{A N}$ & & & & & & \\
\hline 9. & Kredibilitas petugas pelayanan & 7 & 32 & 79 & 32 & 9 & 34 & 79 & 28 \\
\hline 10 & $\begin{array}{l}\text { Ketepatan waktu petugas } \\
\text { menyelesaikan pelayanan. }\end{array}$ & 9 & 31 & 82 & 28 & 8 & 29 & 78 & 35 \\
\hline 5. & TANGGUNG JAWAB PETUG & S PEL & YAN & & & & & & \\
\hline 11. & Kejelasan tanggung jawab & 7 & 33 & 84 & 26 & 8 & 28 & 78 & 36 \\
\hline 12. & petugas pelayanan. & 5 & 36 & 78 & 31 & 6 & 34 & 80 & 30 \\
\hline 13. & $\begin{array}{l}\text { Kepastian tanggung jawab } \\
\text { petugas pelayanan. } \\
\text { Keterbukaan tanggung jawab } \\
\text { petugas pelayanan }\end{array}$ & 4 & 28 & 69 & 49 & 5 & 38 & 81 & 26 \\
\hline 6. & KEMAMPUAN PETUGAS PE & AYAN & & & & & & & \\
\hline 14. & Kemampuan fisik petugas & 7 & 39 & 81 & 23 & 7 & 41 & 77 & 25 \\
\hline 15. & Kemampuan intelektual petugas & 4 & 33 & 74 & 39 & 5 & 30 & 73 & 42 \\
\hline 16. & $\begin{array}{l}\text { Kemampuan administrasi } \\
\text { petugas. }\end{array}$ & 9 & 39 & 76 & 26 & 8 & 37 & 83 & 22 \\
\hline 7 & KECEPATAN PELAYANAN P & ETUG & & & & & & & \\
\hline 17. & Ketepatan waktu pelayanan. & 9 & 36 & 80 & 25 & 9 & 38 & 79 & 24 \\
\hline 18. & $\begin{array}{l}\text { Keterbukaan waktu } \\
\text { penyelesaian pelayanan. }\end{array}$ & 8 & 31 & 77 & 34 & 8 & 34 & 76 & 32 \\
\hline 8. & KEADILAN MENDAPAATKA & N PEL & YAN & & & & & & \\
\hline 19. & Kesamaan perlakuan dalam & 10 & 32 & 90 & 18 & 11 & 28 & 79 & 32 \\
\hline 20. & $\begin{array}{l}\text { mendapatkan pelayanan } \\
\text { Kemerataan jangkauan / } \\
\text { cakupan dalam pelaksanaan } \\
\text { pelayanan. }\end{array}$ & 8 & 30 & 87 & 25 & 9 & 31 & 71 & 39 \\
\hline 9. & KESOPANAN DAN KERAMA & IAN P & TUG & & & & & & \\
\hline 21. & Kesopanan dan keramahan oleh & 4 & 32 & 81 & 33 & 6 & 35 & 75 & 34 \\
\hline 22. & $\begin{array}{l}\text { petugas pelayanan } \\
\text { Penghormatan dan penghargaan } \\
\text { petugas dengan masyarakat. }\end{array}$ & 5 & 38 & 83 & 24 & 7 & 38 & 80 & 25 \\
\hline 10. & KEWAJARAN BIAYA PELAY & ANAN & & & & & & & \\
\hline 23. & Keterjangkauan biaya oleh & 21 & 48 & 58 & 23 & 21 & 53 & 62 & 14 \\
\hline 24. & $\begin{array}{l}\text { kemampuan masyarakat. } \\
\text { Kewajaran besarnya biaya } \\
\text { pelayanan dengan hasil } \\
\text { pelayanan. }\end{array}$ & 19 & 50 & 64 & 17 & 19 & 60 & 57 & 14 \\
\hline
\end{tabular}




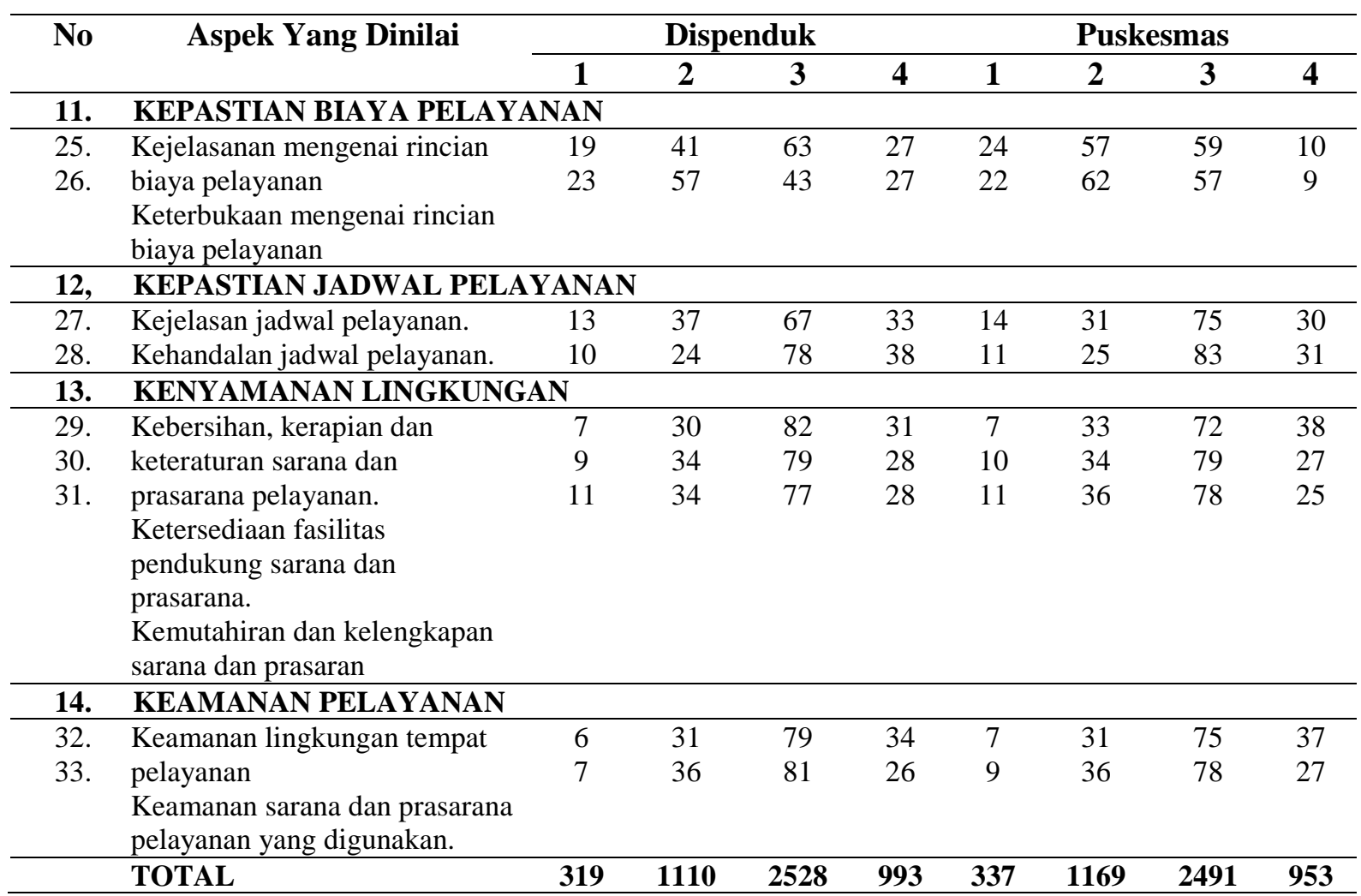

Berikut ini akan disajikan hasil temuan dalam penelitian ini mengenai kepuasan masyarakat akan kualitas pelayanan pada SKPD di Surabaya yang terdiri dari:

1. Prosedur pelayanan

Indikator prosedur pelayanan dalam penelitian ini terdiri dari $3 \mathrm{sub}$ indikator untuk pertanyaan yaitu tingkat keterbukaan informasi mengenai prosedur pelayanan untuk pertanyaan nomor 1, tingkat kejelasan kejelasan alur dalam prosedur pelayanan untuk pertanyaan nomor 2, dan tingkat kesederhanaan prosedur pelayanan untuk pertanyaan nomor 3. Berdasarkan data hasil penelitian dan setelah dilakukan tabulasi data maka diperoleh kenyataan bahwa mayoritas responden menyatakan kondisi pelayanan yang berhubungan dengan unsur prosedur pelayanan yang terdiri dari tiga indikator tersebut diatas sudah baik dimana 70 - 79 persen responden menyatakan demikian, hanya sebagian kecil (10 - 13 persen) yang menyatakan kondisinya tidak baik seperti yang (keterangan selengkapnya dapat dilihat dalam Lampiran Output Hasil Penelitian). Ketiga kriteria yaitu keterbukaan informasi, kejelasan alur dan kesederhanaan prosedur dinilai oleh sebagian besar responden sudah baik, hal ini dikarenakan adanya informasi yang jelas dari pihak Pemerintah daerah dalam hal ini SKPD yang bersangkutan berupa papan pengumuman maupun informasi yang lain yang mudah diakses oleh masyarakat pengguna layanan ini. 
Selanjutnya apabila keseluruhan sub indikator di atas dilihat berdasarkann bobot skor yang telah diperoleh maka akan diperoleh bobot rata-rata sebesar 454,33, sehingga nilai skor untuk prosedur pelayanan adalah sebesar 3,03 sehingga dapat dikategorikan dalam kondisi yang baik. Berdasarkan hasil wawancara bahwa secara keseluruhan kinerja prosedur pelayanan dapat dikatakan baik. Hal ini ditunjukkan dengan keseluruhan sub indikatornya berada pada kondisi yang baik seperti keterbukaan akan informasi persyaratan, kejelasan alurnya dalam prosedur pelayanan, dan kesederhanaan prosedur.

Masyarakat merasa sangat terbantu sekali dengan apa yang telah dilakukan oleh Puskesmas terutama dalam hal sosialisasi mengenai prosedur dan tata cara memperoleh layanan kesehatan, sehingga sangat jelas bagi mereka tentang apa yang harus disertakan dan dipersiapkan. Bila dilihat dari tingkat kepentingannya dari segi prosedur pelayanan maka dapat dikatakan hampir semua responden memberikan penilaian antara penting dan sangat penting. Seperti dalam lampiran hanya terdapat 3 responden yang menyatakan tidak penting mengenai prosedur pelayanan terutama dalam sub indikator kejelasan alur. Dengan melihat tingkat kepentingan yang cukup tinggi ini menandakan bahwa masyarakat sangat menginginkan adanya kejelasan informasi dan prosedur pelayanan yang terbuka guna memperoleh layanan kesehatan. Prosedur yang jelas dan mudah dimengerti merupakan langkah awal agar masyarakat menjadikan sebagai alternatif pertama dalam memperolah layanan kesehatan. Secara keseluruhan tingkat kepentingan untuk prosedur pelayanan mempunyai bobot nilai sebesar 495,33 dan bila di bandingkan dengan kualitas pelayanan yang dirasakan oleh responden mempuyai bobot nilai sebesar 0,917.

Artinya 91,7 persen keinginan ataupun harapan masyarakat mengenai prosedur pelayanan telah mampu dijalankan dengan baik.

2. Persyaratan Pelayanan

Indikator persyaratan pelayanan dalam penelitian ini terdiri dari 3 sub indikator untuk 3 pertanyaan yaitu tingkat keterbukaan mengenai persyaratan pelayanan untuk pertanyaan nomor 4, tingkat kemudahan dalam mengurus dan memenuhi persyaratan pelayanan untuk pertanyaan nomor 5, dan tingkat kejelasan mengenai persyaratan pelayanan untuk pertanyaan nomor 6 . Berdasarkan hasil wawancara dengan responden diperoleh data hasil penelitian seperti yang terlihat dalam lampiran yang berkaitan dengan indikator persyaratan pelayanan. Mayoritas responden $(84,75 \%)$ menyatakan tingkat kemudahan persyaratan pelayanan adalah mudah demikian mengenai tingkat keterbukaan, dan kejelasan persyaratan pelayanan oleh responden dinyatakan dalam keadaan yang baik, hal ini dibuktikan dengan 80 persen lebih responden menyatakan demikian dan hanya sebagian kecil responden yang menyatakan bahwa kualitas dalam hal persyaratan pelayanan adalah tidak baik.

Hasil tabulasi dari ketiga sub indikator menghasilkan bobot rata-rata sebesar 438 dengan nilai skor sebesar 2,92 sehingga secara keseluruhan indikator persyaratan pelayanan dalam kondisi yang baik. Persyaratan untuk 
mendapatkan pelayanan menjadi sangat penting mengingat masyarakat di sekitar wilayah kerja Puskesmas maupun Dispenduk Surabaya harus memenuhinya agar mendapatkan pelayanan seperti yang diharapkan. Bila sebelumya persyaratan sudah disosialisasikan dengan baik maka masyarakatpun akan dapat dengan mudah mempersiapkan baik dari sisi administrasi maupun teknisnya. Untuk mengetahui tingkat kepentingan persyaratan pelayanan dari pengguna jasa dapat dilihat dari kolom kepentingan dari item pertanyaan untuk indikator yang sama. Hasil yang diperoleh menggabambarkan lebih dari 80 persen responden menyatakan bahwa kemudahan persyaratan pelayanan adalah penting dan $18 \%$ menyatakan sangat penting, hanya seorang responden yang menyatakan tidak penting. Demikian juga dengan tingkat kepentingan sub indikator yang lain baik mengenai keterbukaan dan kejelasan akan persyaratan tersebut mayoritas responden juga menyatakan hal yang sama yaitu antara penting hingga sangat penting, hanya kecil sekali prosentase dari responden yang menyatakan tidak penting. Oleh karena itu secara keseluruhan untuk indikator tingkat kepentingan akan persyaratan pelayanan oleh responden merupakan hal yang penting hal ini dapat dilihat berdasarkan nilai rata-rata dari keseluruhan sub indikator ini sebesar 475,67 dengan skor nilai sebesar 3,17 yang artinya responden menganggap penting akan persyaratan pelayanan.

Sementara itu tingkat kesesuaian antara harapan dengan kenyataan dapat dilihat dari perbandingan tingkat kepentingan dengan kepuasan mengenai kulaitas pelayanan dalam hal persyaratan pelayanan. Dengan skor nilai 438 pada tingkat kepuasan kualitas pelayanan dan 475,67 pada tingkat kepentingan maka diperoleh tingkat kesesuaian sebesar 0,921 yang artinya sudah 92,1 kepentingan responden pemakai jasa sudah terlayani dalam hal persyaratan penelitian.

3. Kejelasan Petugas Pelayanan

Indikator kejelasan petugas pelayanan dalam penelitian ini terdiri dari 2 sub indikator untuk 2 pertanyaan yaitu tingkat kepastian mengenai identitas dan tanggung jawab petugas pelayanan untuk pertanyaan nomor 7 dan tingkat kemudahan petugas pelayanan untuk ditemui dan dihubungi untuk pertanyaan nomor 8 dapat diperoleh gambaran mengenai tingkat kepuasan masyarakat dari sub indikator tingkat kepastian identitas dan tanggung jawab, dimana 2,7\% responden menyatakan sangat pasti dan $80,6 \%$ responden menyatakan pasti. Sedangkan $11,3 \%$ responden menjawab tidak pasti.

Sementara itu mengenai kemudahan dalam menghubungi dan menemui sebanyak $18 \%$ responden menjawab tidak mudah dan mayoritas responden (80\%) responden menyatakan mudah ditemui hanya $2 \%$ responden saja yang menyatakan sangat mudah untuk ditemui.. Bila secara keseluruhan apabila kedua sub indikator dirata-rata, maka akan diperoleh bobot sebesar 431,5 dan rentang skor 2,88. Berdasarkan rentang skor yang ada dapat dikatakan bahwa kepuasan akan kualitas kejelasan petugas. Puskemas berada dalam kondisi bagus dibanding dengan Dispenduk. 
Namun tidak dapat dipungkiri bahwa kadang beberapa pasien tidak dapat dengan mudah untuk menemui petugas pelayanan yang berkompeten seperti dokter umum yang tidak berada ditempat sehingga dia akhirnya dilayani oleh bidan jaga yang berada di lokasi. Namun sebagai langkah perbaikan Puskesmas telah meninkatkan kualitas dan kuantitas SDM nya khususnya dokter dengan menambah personel menjadi 4 (empat) orang dokter umum disamping tetap dibantu oleh paramedis yang lain. Sedangkan Dispenduk meski memiliki SDM yang cukup namun tetap saja tidak mampu memberikan pelayanan yang lebih baik

Bagaimanakah tingkat kepentingan dari masyarakat pengguna jasa layanan, apakah bagi mereka kejelasan identitas dan kemudahan dihubungi menjadi persoalan yang penting? Hal ini dapat dilihat dari tingkat kepentingan masyarakat khususnya untuk indikator kejelasan petugas pelayanan. Dari kedua sub indikator menunjukkan bahwa mayoritas responden yaitu sebesar $80 \%$ lebih responden menyatakan penting dan sisanya menyatakan sangat penting akan kejelsan petugas pelayanan. Dalam lampiran dinyatakan bahwa terdapat sebanyak 130 responden $(86,7 \%)$ yang menyatakan penting akan kemudahan menemui dan menghubungi petugas pelayanan sementara sisanya menyatakan sangat penting.

Bagi masyarakat kejelasan mengenai keberadaan dan petugas pelayanan dan kemudahan untuk menemui adalah sangat berguna mengingat tidak jarang sudah ada pasien yang membutuhkan penanganan tetapi terkendala masalah administrasi karena yang mengurusi baru keluar ataupun petugas medisnya yang tidak berada di tempat. Sebaliknya untuk pelayanan Dispenduk,masyarakat seringkali kecewa karena ketidakjelasan petugas yang menangani pelayanan karen terkesan sering melempar tanggung jawab. Kejelasan identitas dan tanggung jawab memberikan pedoman yang jelas bagi masyaraka untuk dapat berkomunikasi mengenai dalam memenuh kebutuhn pelayanan.

Berdasarkan hasil tingkat kepuasan dan kepentingan akan kejelasan petugas pelayanan, maka diperoleh tingkat kesesuaian sebesar 0,914 yang artinya sudah $91,4 \%$ kepuasan masyarakat terpenuhi oleh pelayanan pelayanan petugas.

4. Kedisiplinan Petugas Pelayanan

Indikator kedisiplinan petugas pelayanan dalam penelitian ini terdiri dari 2 sub indikator yaitu tingkat kredibilitas petugas pelayanan untuk pertanyaan nomor 9, tingkat ketepatan waktu petugas dalam menyelesaikan suatu pelayanan untuk pertanyaan nomor 10. Berdasarkan data mengenai tingkat kedisiplinan petugas pelayanan dapat dinyatakan bahwa mayoritas responden menyatakan petugas pelayanan sudah cukup disiplin baik dari segi kredibilitas dan ketepatan waktu dalam menyelesaikan pelayanan. Mengenai tingkat kredibilitas dapat digambarkan bahwa $20 \%$ responden menyatakan petugas tidak kredibel, $77,3 \%$ responden menyatakan petugas pelayanan kredibel dan 
2,7\% responden sangat kredibel. Sementara mengenai tingkat ketepatan petugas dalam menyelesaikan pelayanan dapat dinyatakan sebagai berikut : hanya ada 1 orang responden yang menyatakan sangat tidak tepat, $10 \%$ responden menyatakan tidak tepat $86 \%$ responden menyatakan tepat waktu dan 3,3\% responden menyatakan sangat tepat waktunya dalam menyelesaikan pelayanan.

Hal tersebut sudah sesuai dengan apa yang dituangkan dalam standar operasional prosedur (SOP) masing-masing SKPD. Tingkat kepuasan masyarakat yang cukup tinggi akan indikator ini menandakan bahwa pelayanan sudah seperti yang digariskan dalam SOP.

Selanjutnya apabila bobot nilai keseluruhan sub indikator dirata-rata, maka akan diperoleh bobot sebesar 432 dan skor yang diperoleh sebesar 2,88. Berdasarkan rentang skor yang ada dapat dikatakan bahwa kinerja kedisiplinan petugas pelayanan berada dalam kondisi yang baik. mengenai tingkat kepentingan kredibilitas petugas pelayanan dapat dinyatakan bahwa terdapat 125 responden atau sekitar 83,3\% menganggap menganggap penting dan sebanyak 25 responden atau sekitar 16,7\% memberikan penilaian sangat penting.

Tingkat kepentingan dari indikator kedisiplinan petugas pelayanan berdasarkan wawancara dengan responden adalah sangat penting yaitu dengan rata-rata bobot nilai sebesar 488,5 dengan rentang nilai sebesar 3,26. Sementara bila dihitung tingkat kesesuaian antara kepentingan dengan kepuasan masyarakat maka akan diperoleh nilai sebesar 0,884 dimana 88,4 \% akan tingkat kedisiplinan petugas pelayanan telah memberikan kepuasan terhadap masyarakat pengguna jasa layanan Puskesmas maupun Dispenduk

5. Tanggung Jawab petugas pelayanan

Indikator tanggung jawab petugas pelayanan dalam penelitian ini terdiri dari 3 sub indikator yaitu tingkat kejelasan tanggung jawab petugas pelayanan untuk pertanyaan nomor 11, tingkat kepastian tanggung jawab petugas pelayanan untuk pertanyaan nomor 12, dan tingkat keterbukaan tanggung jawab petugas pelayanan untuk pertanyaan nomor 13 menunjukkan salah satu sub indikator dari tanggung jawab petugas pelayanan khususnya mengenai tingkat kejelasannya. Terdapat 23 orang responden atau 15,3\% menyatakan tidak jelas, mayoritas responden atau 82,7 persen menyatakan sudah jelas akan tanggung jawab petugas dan sehingga mereka puas akan pelayanannya. Demikian juga untuk sub indikator yang lain seperti tingkat kepastian dan keterbukaan tanggung jawab, menurut responden sudah jelas dan baik. Hal ini mengindikasikan tanggung jawab petugas pelayanan akan fungsi dan tugasnya masing-masing sudah dilaksanakan dengna baik. Hal ini juga dapat dilihat dari rata-rata bobot nilai dari sub indicator yang mencapai 427,67 dengan rentang nilai sebesar 2,85 yang berada dalam rentang kondisi baik, menggambarkan tingkat kepentingan mengenai kejelasan tanggung jawab petugas pelayanan Mayoritas responden $(63,3 \%)$ menyatakan penting dan selebihnya $(36,7 \%)$ menyatakan sangat penting mengenai kejelasan tangggung jawab petugas 
pelayanan. Bila dilihat dari tingkat kepentingan dari indikator tanggung jawab petugas pelayanan, semua responden menyatakan penting hingga sangat penting baik dari kejelasan, kepastian hinga keterbukaan tanggung jawab mengingat tanggung jawab pelayanan akan sangat berpengaruh terhadap keberhasilan pelayanan yang berkualitas. Untuk lebih jelasnya dapat dilihat dalam

Lampiran Output hasil penelitian mengenai tingkat kepentingan. Dari ketiga sub indikator ini diperoleh rata-rata bobot nilai sebesar 505 dengan rentang skor sebesar 3,37 yang berarti menurut responden tanggung jawab petugas pelayanan adalah sangat penting. Selanjutnya apabila dilihat dari tingkat kesesuaian antara tingkat kepuasan dengan tingkat kepentingan akan diperoleh nilai seebesar 0,847 yang artinya 84,7\% kepentingan pengguna layanan sudah terpenuhi oleh kualitas kinerja tanggung jawab dari para petugas pelayanan.

6. Kemampuan petugas Pelayanan

Indikator kemampuan petugas pelayanan dalam penelitian ini terdiri dari 3 sub indikator dalam 3 pertanyaan yaitu tingkat kemampuan fisik petugas untuk pertanyaan nomor 14, tingkat kemampuan intelektual untuk pertanyaan nomor 15, dan tingkat kemampuan administrasi untuk pertanyaan nomor 16menggambarkan bahwa responden mulai meragukan kemampuan fisik petugas, hal ini terlihat dimana terdapat 56 orang responden $(37,3 \%)$ menyatakan bahwa petugas tidak mampu, 92 orang responden $(61,3 \%)$ dan 2 orang $(1,3 \%)$ menyatakan petugas mampu dan sangat mampu secara fisik. Sementara bila dilihat dari kemampuan intelektualnya, sebanyak 23 orang responden $(15,3 \%)$ menyatakan petugas tidak mampu, 126 orang $(84 \%)$

menyatakan mampu dan hanya 1 orang responden yg menyatakan sangat mampu. Walaupun sebagian besar responden menyatakan baik secara fisik, intelektual dan administrasi petugas mampu dalam memberikan pelayanan, namun keraguan responden mulai muncul akan kemampuan petugas terutama dalam hal kemampuan fisik dan administrasi. Kemampuan intelektual memang sudah tidak diragukan lagi karena SDM yang ada merupakan orang yang ahli dan berkompeten dalam bidangnya dan juga pengalaman yang cukup lama akan memberikan nilai tambah bagi petugas. Namun secara fisik dan administrasi oleh responden mulai diragukan kemampuannya hal ini dapat disebabkan oleh memang kondisi fisik yang sudah menurun sejalan dengan usia para petugas karena memang sudah mengabdi cukup lama. Dari ketiga sub indikator tersebut, semuanya dinilai oleh responden dalam kategori yang tidak baik karena rentang nilainya sebesar 2,21 dan 2,39 sehingga secara keseluruhan untuk indikator kemampuan petugas mempunyai bobot nilai 336,67 dengan rentang nilai sebesar 2,31 yang berarti dinilai oleh responden dalam kondisi tidak baik. Dari pengamatan di lokasi penelitian dijumpai petugas yang sudah berumur dan puluhan tahun bekerja. Hal ini mengakibatkan kemampuan fisik mereka juga berkurang, disamping itu lemahnya kemampuan administrasi 
dikarenakan petugas yang memang mengurusi bagian administrasi jumlahnya dinilai masih kurang sehingga tidak jarang masyarakat harus menunggu cukup lama menunggu proses administrasi oleh petugas selesai.

Ketidakmampuan petugas pelayanan menurut persepsi responden lebih disebabkan oleh faktor internal sumber daya manusia mengingat masih ada beberapa petugas baik di Puskesmas maupun di Dispenduk yang berpendidikan SLTA dan sederajat, selain itu faktor usia juga ikut berpengaruh karena komposisi pegawai puskesmas lebih banyak yang berusia 40 tahun keatas.

Bila dilihat dari tingkat kepentingan responden akan kemampuan petugaspelayanan maka hampir semua responden menyatakan penting bahkan sangat penting mengingat kemampuan tersebut sangat diperlukan dalam menangani masalah-masalah kesehatan pasien. Dengan rata-rata bobot nilai sebesar 498,67 dan rentang skor sebesar 3,32, hal ini berarti untuk indikator kemampuan petugas oleh responden dinilai sangat penting. Sehingga bila dilihat dari tingkat kesesuaian antara tingkat kepentingan dengan kepuasan responden diperoleh nilai sebesar 0,695 yang berarti $69,5 \%$ tingkat kepentingan responden udah terlayani dalam hal kemampuan petugas pelayanan. Namun masih harus perlu peningkatan kemampuan sumber daya manusia agar dikemudian hari keraguan masyarakat akan kemampuan petugas dapat diminimalkan.

7. Kecepatan pelayanan

Indikator kecepatan pelayanan dalam penelitian ini terdiri dari 2 sub indikator dalam 2 pertanyaan yaitu tingkat ketepatan waktu proses pelayanan untuk pertanyaan nomor 17 dan tingkat keterbukaan waktu penyelesaian pelayanan untuk pertanyaan nomor 18. Dalam tabel berikut disajikan data hasil penelitian yang berkaitan dengan indikator kecepatan pelayan, maka dapat dikatakan bahwa secara umum kebanyakan responden $(48,7 \%)$ menyatakan tepat waktu dalam proses pelayanan, namun lebih dari $50 \%$ responden menyatakan tidak tepat bahkan sangat tidak tepat. Untuk sub indikator ini responden memberikan penilaian tidak baik karena rentang skornya dibawah 2,5. Sementara mengenai keterbukaan waktupenyelesaiaan pelayanan oleh responden dinilai sudah baik, mayoritas responden menyatakan terbuka sebanyak $80,7 \%$.

Dispenduk maupun Puskesma telah menerapkan standar waktu pelayanan untuk masing-masing tindakan, jadi untuk setiap penanganan medis waktu penyelesaian sudah baku tetapi sebelum proses tindakan medis pasien terlebih dahulu harus menunggu antrean terkadang cukup lama karena keterbatasan sumber daya. Hal ini mengakibatkan kepuasan masyarakat menjadi berkurang.

Bila dilihat berdasarkan indikator penilaian, apabila kedua sub indikator tersebut dirata-rata akan diperoleh bobot nilai sebesar 389 sehingga rentang skor yang diperoleh sebesar 2,59 yang artinya responden memberikan penilaian terhadap kinerja kecepatan pelayanan berada dalam kondisi yang baik. Tingkat kepentingan terhadap indikator ini oleh responden dinilai sangat penting, hal ini 
dapat dipahami mengingat masyarakat yang datang membutuhkan pelayanan, namun bila waktunya hanya dihabiskan untuk menunggu giliran saja sudah cukup lama maka akan mempengaruhi kepuasan masyarakat. Bila dilihat dari tingkat kesesuaian antara kepuasan dengan kepentingan masyarakat akan pelayanan khususnya dari indikator ini akan diperoleh nilai 0,8 yang artinya $80 \%$ kepentingan masyarakat sudah mampu terlayani dengan baik.

8. Keadilan Mendapatkan Pelayanan.

Indikator keadilan mendapatkan pelayanan dalam penelitian ini terdiri dari 2 sub indikator dalam 2 pertanyaan yaitu tingkat kesamaan perlakuan dalam mendapatkan pelayanan untuk pertanyaan nomor 19 dan tingkat kemerataan jangkauan cakupan dalam pelaksanaan pelayanan untuk pertanyaan nomor 20 .

Dalam Tabel berikut disajikan data hasil penelitian yang berkaitan dengan indikator keadilan mendapatkan pelayanan, menggambarkan bahwa ada 27 orang responden atau sekitar $18 \%$ memberikan pernyataan kalau ada perbedaan perlakuan dari petugas dalam mendapatkan pelayanan, sementara sebagian besar responden yaitu sekitar 79,3\% menjawab sama perlakuannya dan hanya $2,7 \%$ responden yang memebrikan jawaban sangat sama. Sementara tabel 4.25 menggambarkan tingkat kemerataan cakupan pelayanan, dimana hampir sama dengan abel sebelumnya bahwamayoritas responden yaitu sekitar 119 orang atau 79,3\% menyatakan merat cakupan pelayanannya.

Berdasarkan hasil tabulasi data diperoleh informasi bahwa mayoritas responden memberikan penilaian yang baik untuk indikator keadilan mendapatkan pelayanan. Hal ini dapat dilihat dari penilaian mereka terhadap masing-masing sub indikator kesamaan perlakuan dan kemerataan dalam pelayanan. Jadi petugas pelayanan dalam meberikan layanan kepada masyarakat adalah sama tanpa membedakan status mereka, apakah dari warga mampu ataupun tidak mampu seperti Gakin dan Askeskin. Keadilan pelayanan ini oleh responden merupakan hal yang sangat penting bila dilihat dari tingkat kepentingannya. Hal ini tentunya akan meningkatkan kepuasan bagi masyarakat pengguna jasa layanan karena sebagian adalah masyarakat menengah ke bawah.

Tingkat kesesuaiannya menunjukkan angka 0,8 yang berarti $80 \%$ kepentingan masyarakat untuk indikator keadilan dalam pelayanan sudah mampu terlayani dengan baik.

9. Kesopanan dan Keramahan Petugas.

Indikator kesopanan dan keramahan petugas dalam penelitian ini terdiri dari 2 sub indikator dalam 2 yaitu tingkat kesopanan dan keramahan petugas pelayanan untuk pertanyaan nomor 21 dan tingkat penghormatan dan penghargaan antara petugas dengan masyarakat untuk nomor 22. Kesopanan dan keramahan petugas adalah bentuk penghargaan mereka terhadap pasien atau masyarakat. Hal semacam ini sangat dirasakan sekali oleh masyarakat, bila mereka dilayani dengan baik dan sopan serta menghargaimasyarakat maka tingkat kepuasan masyarakat di wilayah kerja Puskesmas tentunya akan meningkat. Berikut disajikan data hasil penelitian yang berkaitan dengan 
indikator kesopanan dan keramahan, mayoritas responden atau lebih dari 70 persen responden merasakan kalau petugas dalam memberikan pelayanan juga disertai dengan sikap yang ramah, sopan serta menghargai keadaan pasien. Walaupun demikian masih juga terdapat sebagian kecil responden yang mengatakan tidak sopan dan tidak ada penghormatan terhadap pasien yaitu sekitar 19 - 23 persen dari total responden. hasil dari kedua sub indikator maka jika bobot nilai dirata-rata akan diperoleh bobot sebesar 442, sehingga diperoleh rentang skor sebesar 2,94 dan dapat dikatakan bahwa peniliaian masyarakat akan indikator kinerja kesopanan dan keramahan petugas pelayanan di Puskesmas maupun Dispenduk berada dalam kondisi baik. Demikian halnya dengan tingkat kepentingan masyarakat akan indikator pelayanan ini Mereka menganggap kesopanan dan keramahan petugas pelayanan adalah hal yang sangat penting karena secara tidak langsung dapat membantu proses penyelesaian kebutuhn mereka Bila dilihat dari tingkat kesesuaiannya maka diperoleh nilai sebesar 0,8 yang berarti $80 \%$ tingkat kepentingan masyarakat sudah terpenuhi dalam hal kesopanan dan keramahan petugas.

10. Kewajaran Biaya Pelayanan

Indikator kewajaran biaya pelayanan dalam penelitian ini terdiri dari 2 sub indikator dalam 2 pertanyaan yaitu tingkat keterjangkauan biaya pelayanan oleh kemampuan masyarakat untuk pertanyaan nomor 23 dan tingkat kewajaran besarnya biaya pelayanan dengan hasil pelayanan untuk pertanyaan nomor 24 . Sesuai dengan edaran dari Pemkot Suraaabya bahwa retribusi Puskesmas bahwa terhitung mulai Januari 2011 seluruh warga tidak dipungut biaya retribusi dengan menunjukkan bukti identitas diri (KTP). Namun bila pengobatan disertai dengan tindakan seperti suntik, laborat maka akan dikenakan biaya sesuai dengan ketentuan yang berlaku. Puskesmas maupun Dispenduk juga telah menetapkan besaran biaya yang harus disediakan oleh pasien. Besaran biaya tersebut tergantung atas pemeriksaan dan tindakan apa yang dilakukan. Kebebasan dari kewajiban membayar hanya berlaku bagi masyarakat yang tidak mampu dengan menunjukkan bukti kartu Gakin, Askeskin (Jamkesmas) atau pengantar dari RT/RW dan Kelurahan.

Berikut disajikan data hasil penelitian yang berkaitan dengan indikator kewajaran biaya pelayanan, memperlihtkan bahwa ada sekitar 24 persen responden yg mengatakan kalau biaya pelayanan tidak terjangkau, sementara itu 63,7 persen menyatakan terjangkau dan sisanya 13,3 persen menyatakan sangat terjangkau. Ketidakterjangkauan ini lebih disebabkan karena persepsi responden yang menganggap kalau pelayanan di Puskesmas adalah gratis termasuk biaya tindakan dan obat. Seperti yang telah dijelaskan tadi bahwa yang gratis adalh retribusinya jadi tidak semuanya gratis kecuali bagi pasien tidak mampu yang dibebaskan dari seluruh biaya pengobatan. Sementara meski pengurusan Akta Kelahiran dan Kartu Keluarga tidak dipungut biaya ,mayoritas responden menyatakan bahwa biaya yang mereka keluarkan adalah wajar sesuai dengan jenis tindakan yang dilakukan. Sehingga untuk tingkat keterjangkauan 
dan kewajaran besarnya biaya pelayanan dengan hasil pelayanan oleh responden dinilai berada dalam kategori yang terjangkau dan wajar. Hal ini dirunjukkan dengan mayoritas responden memberikan penilaian yang baik dalam hal keterjangkauan dan kewajaran biaya. Indikator kewajaran biaya pelayanan dapat dikatan berada dalam kondisi yang bagus karena bobot yang diperoleh dari rata-rata kedua sub indikator menunjukkan angka 442 sehingga skor nilai yang diperoleh sebesar 2,94. Hal ini mengindikasikan kekonsistenan petugas pelayanan dalam memberikan pelayanan kepada masyarakat agar biaya pelayanan menjadi terjangkau, kecuali masyarakat miskin yang memang dibebaskan dari semua biaya pelayanan di Puskesmas

Kewajaran biaya pelayanan oleh mayoritas responden menjadi indikator yang sangat penting, hal ini ditunjukkan dengan nilai rata-rata semua isub indikator sebesar 496 dengan rentang skor sebesar 3,31. Sehingga diperoleh tingkat kesesuaian sebesar 0,9 yang berarti $90 \%$ kepentingan masyarakat akan kewajaran biaya sudah terpenuhi oleh pelayanan.

11. Kepastian Biaya Pelayanan

Indikator kepastian biaya pelayanan dalam penelitian ini terdiri dari 2 sub indikator dalam 2 pertanyaan yaitu tingkat kejelasan mengenai rincian biaya pelayanan untuk pertanyaan nomor 25 dan tingkat keterbukaan mengenai rincian biaya pelayanan untuk pertanyaan nomor 26. Berikut disajikan data hasil penelitian yang berkaitan dengan indikator kepastian biaya pelayanan ada 12 orang responden $(12 \%)$ yang menyatakan rincian biaya pelayanan tidak jelas, sementara mayoritas responden $(78,7 \%)$ mengatakan jelas akan rincian biaya pelayanan dan sisanya yaitu sekitar 9,3 persen mengungkapkan sangat jelas. Sementara mengenai keterbukaan rincian biaya pelayanan gambaran serupa juga terlihat dimana hanya 18 orang responden yang menyatakan tidak terbuka selebihnya yaitu sekitar 77,3 persen dan 10,7 persen responden menyatakan terbuka dan sangat terbka. Dapat disimpulkan bahwa tingkat kejelasan biaya dan keterbukaan mengenai rincian biaya pelayanan berada dalam kategori jelas dan terbuka mengingat mayoritas responden meyatakan jelas dan terbuka mengenai rincian biaya.

Kedua indikator itu selanjutnya bila dirata-rata, maka akan diperoleh bobot sebesar 447, sehingga diperoleh rentang skor 2,98. Berdasarkan rentang skor tersebut menunjukkan tingkat kepuasan masyarakat akan kinerja kepastian biaya pelayanan di Puskesmas berada dalam kondisi baik. Kinerja mengenai kepastian biaya menunjukkan hasil yang positif (baik) hal ini mengindikasikan bahwa mayoritas responden berpendapat bahwa kejelasan dan keterbukaan mengenai rincian biaya sudah dilaksanakan dengan baik sebagaimana yang telah ditetapkan dalam standar operasional prosedur pelayanan.

Untuk tingkat kepentingan indikator ini mayoritas responden memberikan penilaian sangat penting dengan rata-rata bobot nilai dari kedua sub indikator 492 dan rentang skor sebesar 3,28. Sehingga bila dihitung tingkat 
kesesuaiannya didapat nilai sebesar 0,9 yang artinya 90\% kepentingan masyarakat akan kepastian biaya dapat terpenuhi.

12. Kepastian Jadwal pelayanan

Indikator kepastian jadwal pelayanan dalam penelitian ini terdiri dari 2 sub indikator dalam 2 pertanyaan yaitu tingkat kejelasan jadwal pelayanan untuk pertanyaan nomor 27 dan tingkat keandalan jadwal pelayanan untuk pertanyaannomor 28 .

Berikut disajikan data hasil penelitian yang berkaitan dengan indikatorkepastian jadwal pelayanansebagian besar responden (lebih dari 70 persen) dapat dihandalkan bahkan sangat handal. Ada sekitar 25 persen yang mengungkapkan kalau jadwal pelayanan tidak dapat dihandalkan.

Berdasarakan kedua tabel tersebut dapat dijelaskan bahwa baik kejelasan maupun kehandalan jadawal pelayanan dapat dikategorikan dalam kondisi yang baik karena adanya jadwal pelayanan yang jelas dan dapat dipertanggungjawabkan. Selain itu apabila kedua sub indikator tersebut diratarata, maka akan diperoleh bobot sebesar 419 dan berdasarkan nilai tersebut diperoleh skor sebesar 2,79.

Selanjutnya dengan melihat bobot nilai tingkat kepentingan sebesar 502,5 dan rentang skor sebesar 3,35 maka dapat dinyatakan bahwa menurut mayoritas responden kepastian jadwal pelayanan merupakan hal yang sangat penting. Tingkat kesesuaian dapat dihitung dengan membandingkan tingkat kepuasan dengan kepentingan, hasilnya adalah diperoleh tingkat kesesuaian sebesar 0,8 yang berarti $80 \%$ kepentingan masyarakat sudah terlayani dengan baik.

13. Kenyamanan Lingkungan

Indikator kenyamanan lingkungan dalam penelitian ini terdiri dari 3 sub indikator dalam 3 pertanyaan yaitu tingkat kebersihan, kerapian dan keteraturan sarana dan prasarana pelayanan untuk pertanyaan nomor 29, tingkat ketersediaan fasilitas pendukung sarana dan prasarana untuk pertanyaan nomor 30, dan tingkat kemutahiran dan kelengkapan sarana dan prasarana pelayanan untuk pertanyaan nomor 31.

Berikut disajikan data hasil penelitian yang berkaitan dengan indikator Kenyamanan Lingkungan : Berdasarkan ketiga tabel di atas, maka dapat dinyatakan bahwa indikator tingkat kenyamanan lingkungan yang terdiri dari kebersihan lingkungan, ketersediaan fasilitas pendukung serta kelengkapan sarana dan prasarana berada dalam kondisi yang tidak baik. Hal ini dinyatakan oleh sebagian besar responden yang memberikan penilaian minim atas ketiga pertanyaan dari sub indikator tersebut. Sehingga apabila bobot nilai dari ketiga sub indikator tersebut diratarata, maka akan diperoleh bobot sebesar 291,67 dan rentang skor sebesar 1,94.

Tingkat kepentingan akan indikator ini oleh responden dinilia sebagai hal yang sangat penting karena dapat menunjang kenyamanan responden dalam memperoleh layanan kesehatan. Selain itu pula ditunjukkan dengan rata-rata bobot nilai dari ketiga sub indikator yang mencapai 503,33 sehingga diperoleh 
rentang nilai 3,36. berdasarkan hasil penilaian dari tingkat kepuasan dan kepentingan maka dapat diperoleh nilai tingkat kesesuaian sebesar 0,579 yang berarti hanya 57,9 \% kepentingan masyarakat akan kenyamanan lingkungan dapat dipenuhi oleh Puskesmas maupun Dispenduk.

Hasil wawancara dengan responden menunjukkan baik sub indikator pertama, kedua dan ketiga menunjukkan nilai yang negatif (tidak bagus). Hal ini dikarenakan kebanyakan responden mengeluhkan tentang kondisi kenyamanan lingkungan baik itu ruang tunggu dan ketersediaan tempat duduk yang layak. Ruang tunggu dianggap kurang luas dan bersih sedangkan tempat duduk masih kurang. Kemudian kondisi toilet yang kurang bersih juga mengurangi kenyamanan dalam memperoleh layanan. Tidak jarang pasien yang datang harus menunggu sambil berdiri karena kehabisan tempat duduk sehingga mereka merasa tidak nyaman. Selain itu sarana dan prasaranan penunjang pelayanan juga dianggap kurang lengkap sehingga banyak pasien yang hanya mendapatkan perawatan seadanya yang kemudian dirujuk ke rumah sakit untuk mendapatkan penanganan lebih lanjut.

Hasil wawancara dengan responden Dispenduk menunjukkan baik sub indikator pertama dan ketiga menunjukkan nilai yang negatif (tidak bagus). Hal ini dikarenakan kebanyakan responden mengeluhkan tentang kondisi kenyamanan lingkungan baik itu ruang tunggu dan ketersediaan tempat duduk yang layak. Ruang tunggu sudah luas dan bersih namun masyrakat yang mengantri melebihi temoat duduk sehingga banyak yang berdiri bahakan berjubel padahal tidak di imbangi dengan alat penfingin ruangan . Kemudian kondisi toilet yang kurang bersih juga mengurangi kenyamanan dalam memperoleh layanan. sehingga mereka merasa tidak nyaman. Selain itu sarana dan prasaranan penunjang pelayanan juga dianggap kurang lengkap sehingga banyak pasien yang hanya mendapatkan perawatan seadanya yang kemudian dirujuk ke rumah sakit untuk mendapatkan penanganan lebih lanjut

14. Keamanan pelayanan.

Indikator keamanan pelayanan dalam penelitian ini terdiri dari 3 sub indikator dalam 3 pertanyaan yaitu tingkat keamanan lingkungan tempat pelayanan untuk pertanyaan nomor 32, tingkat keamanan dalam penggunaan sarana dan prasarana pelayanan untuk pertanyaan nomor 33. Berikut disajikan data hasil penelitian yang berkaitan dengan indikator keamanan pelayanan : Dilihat dari keamanan lingkungan tempat pelayanan sebagian besar responden (lebih dari $50 \%$ ) menyatakan aman baik di dalam ruangan tempat pelayanan maupun diluar (tempat parkir kendaraan). Namun banyak juga responden yang menyatakan tidak aman sehingga mereka harus waspada terhadap barang bawaan ataupun kendaraan merekaNamun menurut responden mereka lebih merasa tidak aman dengan sarana dan prasarana yang digunakan. Hal ini didasarkan pada kenyataan bahwa mayoritas responden memberikan penilaian tidak aman bahkan sangat tidak aman. Sehingga apabila bobot nilai dari kedua sub indikator dirata-rata, maka akan diperoleh bobot sebesar 329,5 dan skor 
sebesar 2,20. Berdasarkan rentang skor yang ada dapat dikatakan bahwa kualitas dari indikator keamanan lingkungan pelayanan berada dalam kondisi yang tidak baik.

Sementara tingkat kepentingan dari indikator ini berada pada level yang cukup tinggi yaitu dengan bobot nilai 509,5 dan rentang skor 3,40 maka dinyatakan oleh responden adalah sangat penting. Dengan demikian dapat dihitung tingkat kesesuaiannya yaitu sebesar 0,647 yang berarti 64,7\% keepentingan masyarakat akan keamanan pelayanan mampu dipenuhi oleh merupakan gambaran hasil penilaian seluruh indikator yang diteliti dalam penelitian ini. Dari keempat belas indikator penelitian tersebut terdapat sebelas indikator yang dapat dikatakan dalam kategori yang baik, keempat belas indikator tersebut adalah : prosedur pelayanan, persyaratan pelayanan, kejelasan petugas pelayanan, kedisiplinan petugas pelayanan, tanggung jawab petugas pelayanan, kecepatan pelayanan, keadilan mendapatkan pelayanan, kesopanan dan keramahan petugas, kepastian biaya pelayanan, dan kepastian jadwal pelayanan. Sementara terdapat tiga indikator yang menurut responden kategorinya tidak baik yaitu kemampuan petugas, kenyamanan lingkungan dan keamanan lingkungan.

Indikator yang menurut responden dalam kondisi yang paling baik dilihat dari nilai rata-rata unsur adalah indikator prosedur pelayanan sementara indikator yang menurut responden paling buruk kondisinya adalah indikator kenyamanan lingkungan.

\section{Analisis tingkat kesesuaian secara keseluruhan}

Dalam lampiran diterangkan bahwa secara keseluruhan tingkat kesesuaian atas kepuasan pelayanan terhadap kepentinga masyarakat dapat dikatakan cukup tinggi yaitu mencapai $82 \%$. Artinya secara keseluruhan kepentingan masyarakat sudah terlayani dengan baik sebesar 8 persen. Hal tersebut dapat dikatakan suatu pencapaian yang tinggi atas kinerja pelayanandan respon masyarakat pengguna layanan tersebut juga sangat baik.

Setelah menganalisis indikator-indikator kinerja di atas, berikut ini akan dianalisis indeks kepuasan masyarakat (IKM) atas pelayanan di Puskesmas maupun Dispenduk secara keseluruhan. Analisis ini dapat dilakukan dengan cara menghitung nilai indeks dari unit pelayanan kinerja secara keseluruhan, adapun nilai indeks dapat diperoleh dengan cara mengalikan masing-masing nilai rata-rata unsur dengan bobot nilai rata-rata tertimbang. Berdasarkan data dalam maka nilai indeks secara keseluruhan diperoleh angka indek sebesar 2,69 Dengan demikian nilai indeks unit pelayanan Puskemas hasilnya dapat disimpulkan sebagai berikut:
a. Nilai IKM setelah dikonversi
$=$ Nilai Indeks $x$ Nilai penimbang
$=2.53 \times 25$
$=67,41$

b. Mutu pelayanan B.

c. Kinerja unit pelayanan Bagus. 
Sedangkan berdasarkan data dalam maka nilai indeks secara keseluruhan diperoleh angka indek sebesar 2,05 Dengan demikian nilai indeks unit pelayanan Dispenduk hasilnya dapat disimpulkan sebagai berikut:
a. Nilai IKM setelah dikonversi = Nilai Indeks $x$ Nilai penimbang$$
=2,05 \times 25
$$$$
=51,25
$$

b. Mutu pelayanan C

c. Kinerja unit pelayanan Kurang Bagus

Berdasarkan perhitungan di atas, secara keseluruhan indeks kepuasan masyarakat akan pelayanan untuk SKPD Puskesmas dapat dikatakan dalam kondisi yang baik, namun perlu digarisbawahi untuk pelayanan yang diberikan SKPD DispendukCapil yang masih "harus ditingkatkan" karena masih ada beberapa indikator maupun sub indikator yang indeksnya menunjukkan kinerja yang tidak baik.

\section{SIMPULAN}

Berdasarkan hasil analisis pada bab-bab sebelumnya, maka sejumlah poin penting

yang menjadi kesimpulan dari penelitian ini adalah:

1. Kondisi pelayanan administrasi pada Puskesmas sudah baik meski masih dapat ditingkatkan dan Dispenduk masih belum memuaskan. Hal ini karena belum dilaksanakan secara optimal tugas-tugas pelayanan meskipun petugas telah berupaya melakukan perbaikan dalam pelayanan

2. Nilai Indeks Kepuasan Masyarakat (IKM) untuk pelayanan yang diberikan Dispenduk sebesar yang termasuk 51,25 termasuk kategori kurang bagus sedangkan untuk Puskesmas mendapat nilai 67,47 termasuk kategori Baik atau bagus di mana nilai kepuasan tertinggi adalah untuk unsur prosedur pelayanan (3.273) dan nilai kepuasan terendah adalah untuk unsur kepastian biaya pelayanan (2.455).

3. Upaya untuk memperbaiki kinerja pelayanan terutama difokuskan untuk mengatasi kendala internal, yakni proses pelayanan yang masih parsial, sehingga menghambat kemudahan bagi masyarakat dalam mengurus akta kelahiran maupun Kartu Keluarga.

Berdasarkan kesimpulan tersebut, maka sejumlah rekomendasi yang dapat diterapkan untuk meningkatkan kualitas pelayanan pada Dispenduk yang nilainyan kurang bagus maupun Puskesmas yang mendapat nilai Baik adalah:

1. Perlu disusun kebijakan strategis mengenai manajemen pelayanan penanaman yang di dalam kebijakan strategis tersebut mencakup standarisasi pelayanan sehingga masyarakat medapatkan kepastian mengenai standar penyelesaian pelayanan.

2. Menerapkan sistem pelayanan yang lebih praktis dalam arti memangkas prosedur misalnya mengurus Kartu Keluarga masyarakat cukup sampai pada Kelurahan tidak perlu ke Kecamatan bahkan ke Dispenduk dan dapat menunggu 
penyelesaiannya dengan kepastian standar yang jelas sehingga masyarakat tidak perlu bolak balik dan memenuhi kantor Dispenduk. Hal ini menjadikan pelayanan masyaaarakat menjadi lebih cepat dan efisien.

3. Meningkatkan kinerja pelayanan dengan menumbuhkan budya melayani dan menjadi motto petugas bahwa pelyanan yang diberikan haruslah dengan sungguhsungguh, misal Senyum, Sapa,Salam sehingga kinerja yang harus dicapai, sekaligus sebagai acuan dalam melaksanakan kinerja pelayanan.

4. Untuk meningkatkan kualitas pelayanan terutama untuk unsur-unsur kepuasan yang masih berada di posisi bawah dari ke-14 unsur penilaian, maka perlu dilakukan upaya-upaya konkret dan tegas untuk:

a. Menerapkan sanksi yang tegas bagi aparat yang terlibat percaloan dalam pengurusan akte maupun Kartu Keluarga dan untuk pengurusan Jamkeskin , misalnya berupa sanksi administratif mutasi. Sanksi ini juga dapat diterapkan untuk aparat yang melalaikan tugasnya dalam memberikan pelayanan.

b. Menerapkan sistem penilaian mutu kinerja secara obyektif melalui penyusunan dan penerapan Standar Pelayanan Minimal (SPM) dan Standar Operasional Prosedur (SOP), sehingga kapasitas kerja dari tiap aparat dapat dipantau dan kemungkinan penyimpangan dapat dihindarkan sedini mungkin.

c. Mensosialisasikan dan melembagakan budaya kerja profesional melalui penerapan sistem insentif berbasis kinerja, sehingga aparat pelayanan didorong untuk bersikap profesional dalam melaksanakan tugas dan fungsinya dengan jaminan mendapatkan imbalan yang memadai, misalnya dengan memberikan reward bagi aparat yang berprestasi dalam kinerja pelayanan, melakukan pemilihan employee of the month untuk menumbuhkan semangat kompetisi di antara aparat pelayanan, dan lain sebagainya.

d. Meningkatkan kapasitas pelayanan aparat melalui keikutsertaan dalam berbagai program pendidikan dan pelatihan serta kursus-kursus manajemen pelayanan publik, sehingga akan terbentuk mindset aparat pelayanan yang mendahulukan kepuasan pelanggan (customer oriented).

5. Mendorong berbagai inovasi dalam pelayanan penanaman modal, misalnya dengan menggunakan teknologi informasi, sehingga proses pengurusan pelayanan dapat dilakukan secara terintegrasi, terkomputerisasi, dan on-line. Untuk itu, infrastruktur sistem informasi perlu disiapkan untuk mendukung upaya ini. 


\section{DAFTAR PUSTAKA}

Bastian, Indra, Akuntansi Sektor Publik, 2011,Edisi 3,Penerbit Erlangga,Jakarta Bryson, John M., 1995, Strategic Planning for Public and Non Profit Organizations, A Guide to Strengthening and Sustainin Organizational Achievement, Revisied Edition, Josey-Bass Publisher, San-Francisco.

Dwiyanto, Agus, dkk, 2002, Reformasi Birokrasi Publik di Indonesia, diterbitkan Pusat Studi Kependudukan dan Kebijakan UGM, Galang Printika, Yogyakarta.

Dwiyanto, Agus, dkk.2003, Reformasi Tata pemerintahan dan Otonomi Daerah, Pusat

Studi Kepedudukan dan Kebijakan Universitas Gajah Mada, Yogyakarta.

Gasperz, Vincent, 1997. Manajemen Kualitas Dalam Industri Jasa, PT. Gramedia Pustaka, Jakarta

Kepmen PAN No. 25/M.PAN/2/2004 tentang Pedoman Umum Penyusunan Indeks Kepuasan Masyarakat Unit Pelayanan Instansi Pemerintah.

Lane, Jan-Erik, 1995, The Public Sector, Concept, Models and Approaches, Second Edition, Sage Publication, London.

Peraturan Pemerintah Nomor 3 Tahun 2007 , tentang Penyusunan Laporan Penyelenggaraan Pemerintahan Daerah.

Peraturan Menteri Dalam Negeri Nomor 73 tahun 2009, Tentang Tatacara Pelaksanaan Evaluasi Kinerja Penyelenggaraan Pemerintah Daerah.

Rahayu, Amy Y.S. 1996. Fenomena Sektor Publik dan Era Service Quality Servqual), dalam Bisnis dan Birokrasi, Jurnal Ilmu Administrasi dan Organisasi, I : 1 -19

Rahayu, Amy Y.S, Fenomena Sektor Publik dan Era ervice Quality (Servqual), dalam 1996, I : 1-19.

Semil, Nurmah, 2005, Analisis Kinerja Pelayanan Instansi Pemerintah Studi Kasus di Kantor BPN Kota Semarang. Tesis. Semarang : MAP Undip. 